\title{
Major Contribution of Tsunami Deposit Studies to Quaternary Research
}

\author{
Osamu Fujiwara*
}

\begin{abstract}
Large tsunamis are important not only as a serious natural disaster but also a controlling factor in coastal sedimentation processes. Tsunami deposits have been studied in both geological and disaster prevention fields and play an important role in connecting these studies. Large tsunamis cause rapid and large-scale sediment transport in lacustrine, coastal, shallow-marine and deep-marine environments. They play a positive role to form and preserve sand, gravel and shell beds in the geological record. Tsunami deposits probably occupy significant part of coastal geological strata.

Tsunami deposits in the geological records help us to estimate the recurrence interval of subduction-zone earthquakes that cause tsunamis. Histories of such earthquakes inferred from tsunami deposits span 3,000 years for the Nankai and Suruga Troughs, nearly 10,000 years for the Sagami Trough and 6,500 years for the southern Kuril Trench. Tsunami deposits also aid in estimating the relative size of paleotsunamis. Studies in eastern Hokkaido, north Japan, revealed the repeated occurrence of unusually large tsunamis with inundation of several kilometers. These megatsunamis have occurred at about 500-year-intervals over the last 6,500 years along the southern Kuril Trench.

Although some problems and difficulties remain, tsunami deposits are useful for reconstructing tsunami history and evaluating risk of future tsunami events. With the development of methods for differentiating tsunami deposits from other event deposits, and evaluating the hydraulic force and inundation depths, we will be able to learn much about past tsunamis from the deposits and to make use of such information for disaster prevention. Collaboration of a broad range of scientists and engineers, such as geologists, geomorphologists, seismologists, geophysicists and tsunami engineers, would enable to solve existing problems in paleo-tsunami research.
\end{abstract}

Keywords : coastal sedimentation, disaster prevention, Quaternary geology, subduction-zone earthquake, tsunami deposits

\section{Introduction}

Large tsunamis transport a huge volume of sediments and leave behind the deposits both in undersea and onland environments. The deposits transported by tsunamis, tsunami deposits, are sometimes preserved in geological record. Such tsunami deposits have been an important research target over the last two decades in the fields of the Quaternary geology, paleo-seismology, and disaster prevention.

Large tsunamis are an important controlling factor in sediment transport, deposition and preservation processes not only in coastal but also in deep-marine environments. Large-scale sediment transport and deposition in coastal area have been observed in many historical (e.g. Shuto, 1989) and recent tsunamis including the 2004 Indian Ocean tsunami (e.g. Shanmugam, 2006). Conversely, large tsunamis are capable

Received December 6, 2006. Accepted March 8, 2007.

* Active Fault Research Center, National Institute of Advanced Industrial Science and Technology. Central 7, 1-1-1 Higashi, Tsukuba, 305-8567, Japan. E-mail : o.fujiwara@aist.go.jp 
of triggering outgoing sediment flows, transporting sediment to the deep sea bottom as pointed out by Shiki and Yamazaki (1996) and Shanmugam (2006) on the basis of field observation data.

Large tsunamis cause severe consequences in coastal regions, including human casualty and damage to buildings, coastal topography and ecosystems (e.g. Watanabe, 1998 ; Danielsen et al., 2005 ; Matsutomi et al., 2005 ; Tomita et al., 2005 ; Kench et al., 2006). Japanese Islands are at a high risk of tsunami disaster, because of concentrated population and industries in the coastal area facing troughs and trenches along active plate convergent boundaries. Tsunami deposits enable us to reconstruct a long history of subduction-zone earthquakes beyond written records. On the basis of such long and precise tsunami histories, we could forecast future earthquakes and tsunamis and make a plan to mitigate the damage caused by these events.

The purposes of this review paper are summarizing the major contribution of Japanese paleo-tsunami researches in the Quaternary researches and prospecting the direction of fu- ture studies. Japan has the longest history of paleo-tsunami researches in the world and many reports on tsunami deposits (e.g. Fujiwara, 2004). Since the first report by Kon'no (1961), tsunami deposits in the geological record have been reported from various localities throughout the Japanese Islands (Fig. 1). Most of these examples were reported from the Holocene coastal lowland, with rare exceptions from older sedimentary basins.

Tsunamis are mostly caused by subductionzone earthquakes, although, in rare cases, other geological events such as volcanic eruptions, large-scale submarine landslides and extraterrestrial impacts also trigger tsunamis. Therefore, in this report I focus primarily on tsunami deposits on coasts along subduction zones.

Some recently-published text books and special issues of journals offer the history and state of paleo-tsunami research in the world. Bryant (2001) and Satake (2005) provide a general description of tsunamis and their associated sediments. Geological disciplines, including sedimentology and paleontology of tsunami deposits, were published in Shiki et al. (2000)

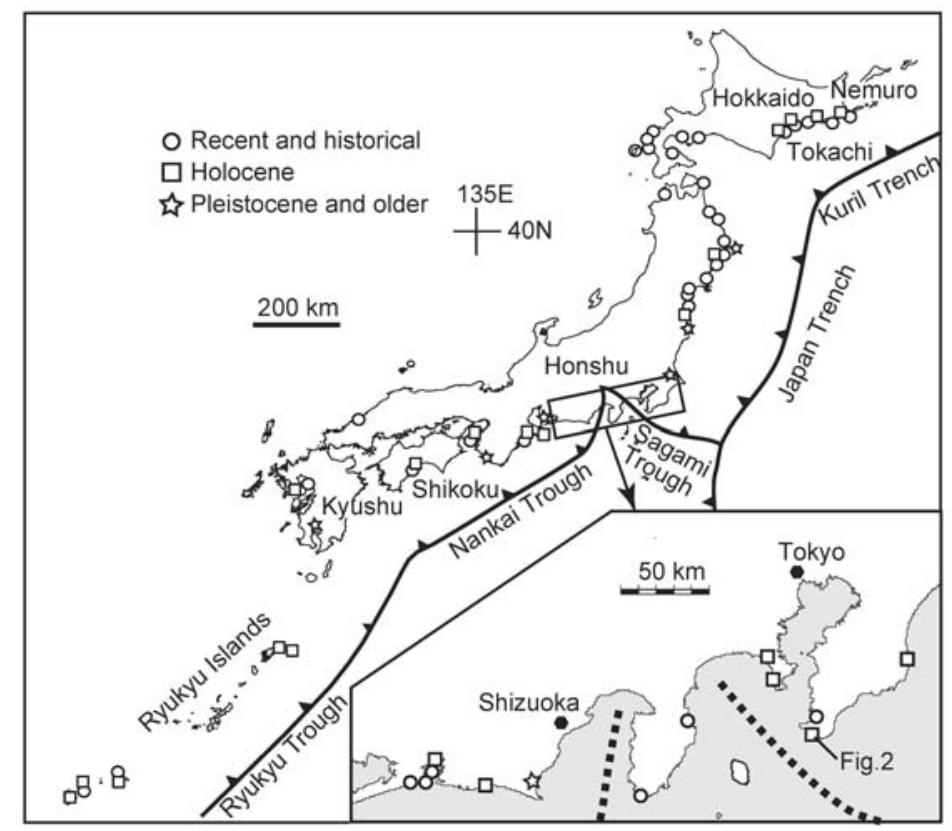

Fig. 1 Regional distribution of tsunami deposits reported from Japanese Islands

Some volcanogenic tsunami deposits are included in examples from western Hokkaido and Kyushu.

Modified from Fujiwara (2004), Komatsubara and Fujiwara (2007) with additional data. 
and Fujiwara et al. (2004). Contribution of paleotsunami studies in mitigating disasters is discussed in Atwater et al. (2005).

\section{Advantages of Japanese researches on tsunami deposits}

Because Japanese Islands face the active plate boundaries, they are fatally apt to be hit by large tsunamis. In addition to tsunamis generated around the Japanese Islands, those generated in distant place, such as the 1960 Chilean tsunami, have hit the islands. Japanese historical documents, back to 1,300 years ago at the longest, have recorded these tsunami events. We can estimate the date and source areas of tsunamis that have occurred in the last 400 years with considerable accuracy, because of abundant documents covering this period.

We can estimate the source of tsunami deposits from comparison with historical records (see the review by Komatsubara and Fujiwara, 2007). Inversely, tsunami deposits can be used to confirm the inundation area (e.g. Minoura et al., 2001) or wave heights (e.g. Takada et al., 2002) of tsunamis that were reported in old documents.

Sedimentation and erosion by tsunamis have also been described in Japanese historical documents in the last few hundred years. Meterslong blocks of coral reef and rock washed ashore by the 1771 Meiwa Tsunami, in Ryukyu Islands, are well known as "tsunami ishi" in Japan (e.g. Kato, 1987). Opening of the mouth of Lake Hamana, central Japan, to connect the Pacific Ocean, by the 1498 Meio Tsunami centered in the Nankai Trough (e.g. Shuto, 1989) is another example of sediment transport by historical tsunami events.

Under these historical and geological backgrounds, scientific researches on tsunami deposits were started in Japan by Kon'no (1961), taking the lead among the world. They reported many traces of the 1960 Chilean tsunami, both of deposition and erosion, widely distributed along the Pacific coast of northeast Japan. Kon'no (1961) found that the tsunami deposit was composed of alternation of several sand sheets and muddy films, in some locations, and they interpreted that the alternate structure resulted from repeated deposition by succeed- ing waves in a tsunami wave train.

Outcrop-scale observations helped geologists to understand the tsunami sedimentation processes. Exposure of the Quaternary shallow marine sequences in Japanese Islands produced by accumulated tectonic uplifts has provided a good condition to observe the sedimentary features of tsunami deposits (e.g. Takashimizu and Masuda, 2000 ; Fujiwara et al., 2003a). Trenching surveys also promoted the precise observation of inner structures of tsunami deposits (e.g. Nanayama et al., 2000). Bedforms and sedimentary structures formed by tractive currents, including dunes and traction carpet (Lowe, 1982, 1988), characterize the tsunami deposits (e.g. Nanayama and Shigeno, 2004 ; Fujiwara and Kamataki, 2007). Hummocky cross stratifications (HCS : Harms et al., 1975 ; Cheel and Leckie, 1993), indicating the deposition from combined flows, characterize the underwater tsunami deposits (Fujiwara et al., 2003a ; Fujiwara and Kamataki, 2007).

Current direction and velocity and settling condition reconstructed from the sedimentary features help us to confirm that the deposits were formed by tsunami.

\section{Contribution to Quaternary geology}

In this section, I summarize major breakthrough in the Quaternary geology produced by researches on tsunami deposits. These researches promoted better understanding of sedimentary processes in coastal region. A new type of sediment transport process generated by tsunami waves was found through these studies.

\section{Coastal sedimentary sequences as stor- age of tsunami deposits}

Paleo-tsunami researches revealed that tsunami deposits are closely related to the development of coastal sequences. Coastal marshes, lakes and lagoons provide a favorable condition for the preservation of tsunami deposits, because of their separation from high-energy waves (e.g. Minoura et al., 1987, 1994 ; Tsuji et al., 1998 ; Nanayama et al., 2003). High fluxes of lithic and organic materials protect tsunami deposits from subsequent erosion and bioturbation.

Closed small bays are also excellent places 
for preservation of tsunami deposits. Fujiwara et al. (1997, 1999, 2000, 2003a) found at least seven tsunami deposits from the middle Holocene muddy bay sequence distributed around the Sagami Trough. Some of these tsunami deposits were correlated with the co-seismic emergence of Holocene marine terraces around the Sagami Trough (e.g. Nakata et al., 1980) by detailed ${ }^{14} \mathrm{C}$ age data, and interpreted as originated in the plate boundary earthquakes along the trough.

Figure 2 shows a representative tsunami deposit which formed $c a$. 7,500-7,400 cal BP in a small bay in the southern Kanto region. It overlies the bay mud with a scoured surface, consists of a stack of several conglomerate sheets and yields abundant exotic shells.

\section{Sediment transport process by tsunami waves}

Identification of tsunami deposits is important, because large paleo-tsunami events have been recognized from their deposits. Reliability of paleo-tsunami study strongly depends on the reliable discrimination of tsunami deposits from other events such as storms. The identification has been a hot topic for geologists since the beginning of paleo-tsunami research. Model- ing sediment transport processes by tsunami waves provides a clue to solve the problem. Although some sedimentological features of tsunami deposits were proposed by previous works (e.g. Dawson et al., 1991 ; Foster et al., 1991 ; Nishimura and Miyaji, 1995 ; Nanayama et al., 2000), definitive criteria to identify the tsunami deposits have not been clarified over the past 15 years. Typical proposed criteria are ; 1) sand sheets showing a tapered cross section with landward thinning, and 2) dislocated huge blocks and wash over sediments indicating much larger run-up height than expected from normal storm waves. These problems were reviewed in Dawson and Shi (2000), Felton and Crook (2003), and Shanmugam (2006).

Tsunamis have 100 times or longer wavelengths and wave periods than those of storms. Because of these wave characteristics, tsunamis form a unique sedimentary features in their deposits as found in the 1703 Kanto tsunami deposit (Fujiwara et al., 2005, 2006) and middle Holocene tsunami deposits (Fujiwara et al., 2003a ; Fujiwara and Kamataki, 2007) in the southern Kanto region (Fig. 3). Here I summarize them into the following four features.

Firstly, alternate stack of sand sheets and

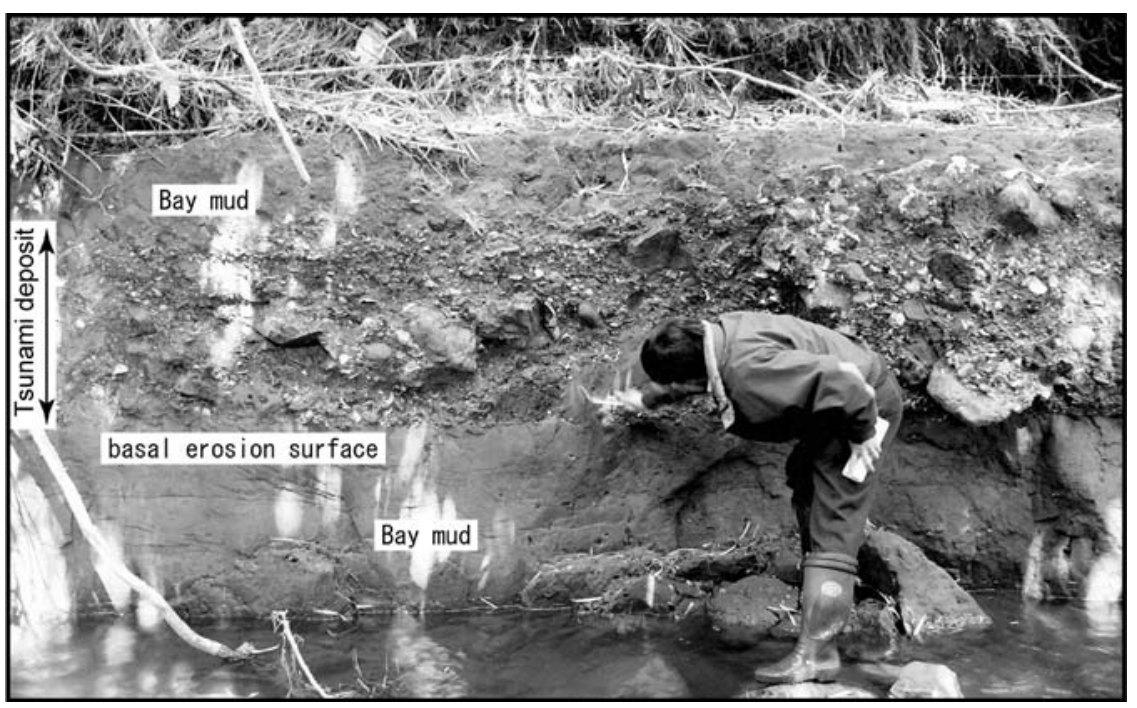

Fig. 2 Tsunami deposit in the middle Holocene bay sequence in the southern Kanto region The tsunami deposit composed of shelly conglomerate formed in a drowned valley with a water depth of $10-20 \mathrm{~m}$. Detailed analyses of sedimentary structure and depositional process of this tsunami deposit is described in Fujiwara and Kamataki (2007). Location of the outcrop is shown in Fig. 1. 


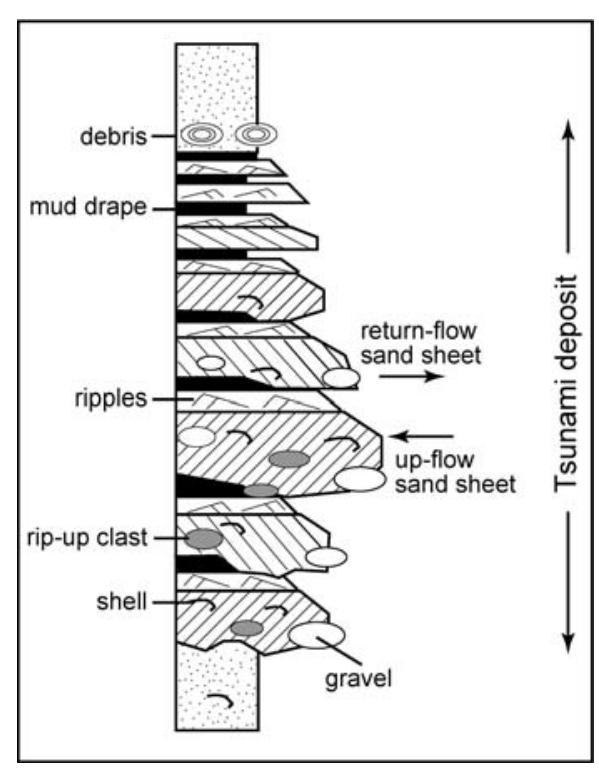

Fig. 3 Prototype geological section showing the tsunami sedimentation process

Four sedimentary features represent long-period runups and backwashes of tsunamis. 1) Alternate stack of sand sheets and mud drapes shows that the deposit is a result of repeated occurrence of high-energy waves.

2) Each sand sheet shows the deposition from a waning sediment flow. 3) Cyclic turnover of flow-directions at tsunami events is shown by the alternate stack of sand sheets deposited from up- and return-flows. 4) A progressive fining-upward trend of the whole deposit represents the waning process of the tsunami.

mud drapes characterize the tsunami deposits. Tsunami wave train with ten-minute-order period is congruent with the alternate stacking pattern in the deposits. Incremental deposition of sand sheets indicates that the deposit resulted from repeated occurrence of high-energy waves. Mud drapes separating each sand sheet was formed during the stagnant stages by suspension fallout.

Secondly, each sand sheet represents the deposition from the individual wave in a tsunami wave train. General fining-upward trend and stacking pattern of the bedforms and sedimentary structures reflect a waning process of the sediment flow. Because of their long wavelengths, up to $100 \mathrm{~km}$, each wave generates a long lasting current, ebb and flood, in coastal regions. Through the waning process of the current, each sand sheet is deposited. In general, lower part is characterized by dunes or large-scale current ripples and includes various size gravels. HCS is sometimes observed. Upper part includes wave ripples and is covered by a mud drape.

Thirdly, cyclic turnover of flow directions reflects the repeated occurrence of up- and returnflows at tsunami events. In Figure 3, flow direction of each sand sheet is shown by inclination of oblique lines.

Finally, a progressive fining-upward trend of the whole deposit represents the waning process of the tsunami. Vertical stack of finer and thinner sand sheets in the upper horizon reflects the progressive decrease in power of successive waves.

These four sedimentary features represent long-period run-ups and backwashes of tsunamis ; storm waves with short wavelengths and wave periods of 10 to 20 seconds at the longest cannot explain the features.

Tsunami deposits with all the above four characters are rare in natural condition. For example, mud drapes and sand sheets may be partly or totally eroded by overlying sand sheets. Figure 3 shows a prototype of depositional model for explaining the tsunami sedimentation process, and further improvement is needed for a wide application.

3. Toward better understanding of sedimentary processes in coastal regions

Tsunami deposits provide an opportunity for geologists to understand the dynamic sedimentary processes during the Late Quaternary. Large-scale rapid depositional events, such as tsunamis and storms, play an important role in the formation and preservation of sediments in coastal regions. Thickly deposited sediment from these catastrophic events occasionally has been preserved in geologic section, surviving from severe physical and biological disturbances.

Sand and gravel beds with exotic shells have been often reported from the Holocene muddy bay sequences in various localities in Japan. In many cases, forming processes of such "unusual" beds have been ambiguously regarded as deposits of storm or flood origin. Tsunami deposits occupy an important part of these 
"unusual" coarse-grained deposits and shell beds as shown by Fujiwara et al. (1997, 1999, 2003b) from the studies in the southern Kanto region.

The shell beds generated by tsunamis have a lenticular shape and alternate with muddy sand layers. This occurrence shows that these beds were formed through the alternation of winnowing stages by strong waves and stagnant stages dominated by suspension fallout. The high diversity in original habitats of molluscan shells, from muddy bay floors to rocky shores, is attributed to erosion and the mixture of sediments around the bays by strong currents. The well preserved condition of the shells indicates rapid deposition and burial during the tsunami events.

With highly dense AMS ${ }^{14} \mathrm{C}$ age data, we can date these geological events with accuracy within 100 years (e.g. Masuda, 1998 ; Fujiwara et al., 2004). Recognition of event deposits, represented by tsunami deposits, and accurate age determination enable us to understand the dynamical development of sedimentary sequences through time.

\section{Contribution to earthquake and tsunami disaster prevention}

We have limited experiences of mega-natural events such as large tsunamis because of their low frequency. Lack of understanding on these mega-events often leads to unprecedented damages by these natural disasters. The 2004 Indian Ocean tsunami and Hurricane Katrina in 2005 are recent examples of such events. Detailed knowledge of the future risks based on the past events would be useful in disaster prevention.

Instrumental and historical records of tsunamis are limited and unable to account for the long recurrence history, 100 years or longer, of great tsunamis. In addition, we cannot directly observe the tsunami source area located deep under the sea. We can, however, use the tsunami deposits in geological records in the same way as we analyze seismograph, tide gauge and old document records.

\section{Reconstruction of tsunami history from deposits in Japan}

A long history of tsunamis covering the later half of the Holocene has been reconstructed from the study of tsunami deposits in Japanese Islands. Discovery of unusually large prehistoric tsunamis from the Pacific coasts of eastern Hokkaido had an impact not only to the Earth scientists but also to general public. Historically, plate boundary earthquakes ranging Mw 7.8-8.2 were the largest in the southern Kuril Trench (Fig. 1) during the last 200 years (see the review by Nanayama et al., 2003 ; Satake et al., 2003). In the eastern Hokkaido, the maximum tsunami height and inundation distance of the 1952 Tokachi-oki earthquake (Mw 8.2) were about $6.5 \mathrm{~m}$ high (Watanabe, 1998) and $1.5 \mathrm{~km}$ (Satake et al., 2003). However, tsunamis that inundated three or more kilometers inland were confirmed by tsunami deposits in the Holocene marsh sequence in this region (e.g. Hirakawa et al., 2000 ; Nanayama et al., 2003). Estimated recurrence interval of these outsize tsunamis from the ${ }^{14} \mathrm{C}$ dating and tephrochronology is about 500 years. The last occurrence of such mega-tsunami event was in the mid 17 th Century.

Along the Nankai, Suruga and Sagami Troughs, historical and prehistoric tsunami deposits have been reported from at least 15 sites (e.g. Okamura et al., 1997 ; Tsuji et al., 1998). Histories of great $(\mathrm{M} \sim 8)$ subduction-zone earthquakes inferred from tsunami deposits span 3,000 years for the Nankai and Suruga Troughs and nearly 10,000 years for the Sagami Trough. The inferred histories contain variable recurrence intervals. The shortest intervals, $100-200$ years for the Nankai Trough and 150-300 years for the Sagami Trough, are similar to those referenced in historical records. Longer intervals inferred from the tsunami deposits probably reflect variability in rupture mode, incompleteness of geologic records, and insufficient research. Details of these results were reviewed in Komatsubara et al. (2006) and Komatsubara and Fujiwara (2007).

\section{Collaborative Work in Geology and Geo- physics}

Collaboration of scientists and engineers is needed to better understand the paleo-tsunamis. Individual study fields, e.g. tsunami geology and tsunami simulations, have both advantages and limitations. On one hand, geological records are incomplete both in space and time. 
On the other hand, geological field survey data are indispensable for evaluating the validity of tsunami numerical simulations.

An excellent example of collaborative work between geology and geophysics regarding tsunami deposits was achieved in the Pacific coast of eastern Hokkaido. In this case, spatial distribution of inundation area and run-up heights of the 17th century gigantic tsunami was estimated from the tsunami deposit (e.g. Nanayama et al., 2003 ; Hirakawa et al., 2005). Then, the earthquake fault parameters such as the location, geometry and distribution of slip on the fault were reconstructed using tsunami numerical simulation (Satake et al., 2004). The results indicate that a multi-segment earthquake (Mw 8.5) off Tokachi and Nemuro (Fig. 1) was most suitable. The study resulted in the publication of map showing the tsunami inundation area in eastern Hokkaido (Satake and Nanayama, 2004). This outcome of paleo-tsunami studies was used for planning a disaster prevention policy by the Japanese government.

\section{Conclusive Remarks}

In this paper, I briefly described the progress of paleo-tsunami research based mainly on my own studies. Though the geological record provides us with much information on past events, we are circumspect in choosing and interpreting the data on paleo-tsunamis. Our knowledge and techniques concerning paleo-tsunami research are not yet complete.

Key problems and prospective goals of paleotsunami research can be summarized as the following three subjects, as already pointed out by Bourgeois and Minoura (1997) and Fujiwara et al. (2004). When these key problems are solved, we will certainly be able to learn much regarding tsunami history from the geological records, and make use of this information for the better understanding of the natural processes and to prevent future disasters.

\section{Reliable identification of tsunami deposits}

Identification of tsunami deposits is a basic problem in paleo-tsunami studies. The criteria and models reviewed in this paper explain the field observation and theoretical tsunami waveforms, but improvement is still needed for con- sideration of wide variety of tsunami deposits and reconstruction of more precise tsunami history. For this purpose, collaborative works among field geology, flume experiments and numerical simulations are needed.

\section{Accurate dating and correlation of events}

Understanding when, where and what regarding the past tsunamis would help us to estimate the features and scale of future tsunami events. Development of database of tsunami deposits, including their temporal and spatial distributions based on detailed age determination, is needed.

\section{Quantitative evaluation of ancient tsunami events}

Evaluation of inundation areas and depths and current velocities of past tsunamis from deposits would be useful for evaluating risk of future tsunami disasters. Eastern Hokkaido is the best field to evaluate the inundation limits of past tsunamis from deposits, because wide uncultivated peaty marshes in this region provide a favorable condition for paleo-tsunami study. In other regions of Japanese Islands, it is difficult to evaluate the inundation limits from deposits, because of poor preservation of tsunami deposits due to small size of costal marsh and artificial disturbances. Development of alternative indexes and techniques for evaluating the scale of past tsunamis from geological records is particularly important

\section{Acknowledgments}

I would like to thank Mr. Y. Sugiyama, Director of Active Fault Research Center (AFRC), AIST, and Dr. K. Goto of Tohoku Univ. for their constructive comments to the manuscript. Thanks are extended also to Dr. K. Satake of AFRC, who edited the English version of this manuscript.

\section{References}

Atwater, B.F., Musumi-Rokkaku, S., Satake, K., Tsuji, Y., Ueda, K. and Yamaguchi, D.K. (2005) The orphan tsunami of 1700 ; Japanese clues to a parent earthquake in North America. 133 p, U.S. Geol. Surv. in association with Univ. of Washington Press.

Bourgeois, J. and Minoura, K. (1997) Paleotsunami studies - contribution to mitigation and risk assessment. Gusiakov, V.K. (ed.) Tsunami mitigation and 
risk assessment : 1-4, Report of the International Workshop, Petropavlovsk-Kamchatsky, Russia, August 21-24, 1996.

Bryant, E. (2001) Tsunami : The underrated hazard. 320 p, Cambridge University Press.

Cheel, R. J. and Leckie, D.A. (1993) Hummocky crossstratification. Wright, V.P. (ed.) Sedimentology review, 1 : 103-122, Blackwell.

Danielsen, F., Sørensen, M.K., Olwig, M.F., Selvam, V., Parish, F., Burgess, N.D., Hiraishi, T., Karunagaran, V.M., Rasmussen, M.S., Hansen, L.B., Quarto, A. and Suryadiputra, N. (2005) The Asian tsunami : A protective role for coastal vegetation. Science, 310, 643.

Dawson, A.G. and Shi, S. (2000) Tsunami deposits. Pure and Applied Geophysics, 157, 875-897.

Dawson, A.G., Foster, I.D.L., Shi, S., Smith, D.E. and Lond, D. (1991) The identification of tsunami deposits in coastal sediment sequences. Science of Tsunami Hazards, 9, 73-82.

Felton, E.A. and Crook, A.A.W. (2003) Evaluating the impacts of huge waves on rocky shorelines : An essay review of the book 'Tsunami-The underrated hazard'. Marine Geology, 197, 1-12.

Foster, I.D.L., Albon, A.J., Bardell, K.M., Fletcher, J.L., Jardine, T.C., Mothers, R.J., Pritchard, M.A. and Tirner, S.E.S. (1991) High energy coastal sedimentary deposits ; and evaluation of depositional processes in southwest England. Earth Surface Processes and Landforms, 16, 341-356.

Fujiwara, O. (2004) Sedimentological and paleontological characteristics of tsunami deposits. Memoirs of the Geological Society of Japan, 58, 35-44. (J $+\mathrm{E})$

Fujiwara. O., Hirakawa, K., Irizuki, T., Kamataki, T., Uchida, J., Abe, K., Hasegawa, S., Takada, K. and Haraguchi, T. (2006) Progradation of Tateyama strand plain system, SW coast of Boso Peninsula central Japan, triggered by coseismic uplifts during the historical Kanto earthquakes. The Quaternary Research (Daiyonki-Kenkyu), 45, 235-247. (J+E)

Fujiwara, O., Ikehara, K. and Nanayama, F. (eds.) (2004) Earthquake-induced event deposits-From deep-sea to on land. 169 p, Memoirs of the Geological Society of Japan, 58.

Fujiwara, O. and Kamataki, T. (2007) Identification of tsunami deposits considering the tsunami waveform : An example of subaqueous tsunami deposits in Holocene shallow bay on southern Boso Peninsula, central Japan. Sedimentary Geology, (in press).

Fujiwara, O., Kamataki, T. and Fuse, K. (2003 b) Genesis of mixed molluscan assemblages in the tsunami deposits distributed in Holocene drowned valleys on the southern Kanto region, east Japan. The Quaternary Research (Daiyonki-Kenkyu), 42, 389412. $(\mathrm{J}+\mathrm{E})$

Fujiwara. O., Kamataki, T., Hirakawa, K., Irizuki, T., Uchida, J., Abe, K. and Hasegawa, S. (2005) Tsunami waveform of the AD1703 Kanto Earthquake recon- structed from the deposit. 2005 AGU Fall Meeting, Program \& Abstracts, T11A-0351.

Fujiwara, O., Kamataki, T. and Masuda, F. (2004) Sedimentological time-averaging and ${ }^{14} \mathrm{C}$ dating of marine shells. Nuclear Instruments and Methods in Physics Research B, 223-224, 540-544.

Fujiwara, O., Kamataki, T. and Tamura, T. (2003a) Grainsize distribution of tsunami deposits reflecting the tsunami waveform: An example from a Holocene drowned valley on the southern Boso Peninsula, east Japan. The Quaternary Research (DaiyonkiKenkyu), 42, 67-81. (J+E)

Fujiwara, O., Masuda, F., Sakai, T., Fuse, K. and Saito, A. (1997) Tsunami deposits in Holocene bay-floor mud and the uplift history of the Boso and Miura peninsulas. The Quaternary Research (DaiyonkiKenkyu), 36, 73-86. (J+E)

Fujiwara, O., Masuda, F., Sakai, T., Irizuki, T. and Fuse, K. (1999) Bay-floor deposits formed by great earthquakes during the past 10,000 yrs, near the Sagami trough, Japan. The Quaternary Research (DaiyonkiKenkyu), 38, 489-501. (J+E)

Fujiwara, O., Masuda, F., Sakai, T., Irizuki, T. and Fuse, K. (2000) Tsunami deposits in Holocene bay mud in southern Kanto region, Pacific coast of central Japan. Sedimentary Geology, 135, 219-230.

Harms, J.C., Southard, J.B., Spearing, D.R. and Walker, R.G. (1975) Depositional environments as interpreted from primary sedimentary structures and stratification sequences. 161 p, SEPM Short Course, 2.

Hirakawa, K. Nakamura, Y. and Echigo, T. (2000) Giant tsunami along the Pacific coast of the Tokachi region. The Earth Monthly (supplement), 31, 92-98. (J)

Hirakawa, K., Nakamura, Y. and Nishimura, Y. (2005) Mega-tsunamis sice last 6,500 years along the $\mathrm{Pa}$ cific coast of Hokkaido. Chikyu Monthly (supplement), 49, 173-180. (J)

Kato, Y. (1987) Run-up height of Yaeyama Sesmic Tsunami (1771). Journal of the Seismological Society of Japan, 40, 377-381. (J+E)

Kench, P.S., McLean, R.F., Brander, R.W., Nichol, S.L., Smithers, S.G., Ford, M.R., Parnell, K.E. and Aslam, M. (2006) Geological effects of tsunami on mid-ocean atoll islands: The Maldives before and after the Sumatran tsunami. Geology, 34, 177-180.

Komatsubara, J. and Fujiwara, O. (2007) Overview of Holocene tsunami deposits along the Nankai, Suruga, and Sagami Troughs, southwest Japan. Pure and Applied Geophysics, 164, 493-507.

Komatsubara, J., Fujiwara, O. and Kamataki, T. (2006) Tsunami deposits along the Nankai Suruga and Sagami troughs. Historical Earthquake (Rekishi Jisin), 21, 93-109. (J+E)

Kon'no, E. (ed.) (1961) Geological observations of the Sanriku coastal region damaged by the tsunami due to the Chile Earthquake in 1960. 40 p, with 13 Plates, Contributions from the Institute of Geology and Palaeontology Tohoku University, 52. $(\mathrm{J}+\mathrm{E})$ 
Lowe, R.D. (1982) Sediment gravity flows : II. Depositional models with special reference to the deposits of high-density turbidity currents. Journal of Sedimentary Petrology, 52, 279-297.

Lowe, R.D. (1988) Suspended-load fallout rate as independent variable in the analysis of current structures. Sedimentology, 35, 765-776.

Masuda, F. (1998) Dynamic stratigraphy based on highly dense data of ${ }^{14} \mathrm{C}$ ages in the Holocene. Journal of Geography, 107, 713-727. (J+E)

Matsutomi, H., Sakakiyama, T., Nugroho, S., Tsuji, Y., Tanioka, Y., Nishimura, Y., Kamataki, T., Murakami, Y., Matsuyama, M. and Kurizuka, K. (2005) The 2004 Indian Ocean tsunami at Banda Aceh and the environs and problems from a viewpoint of damage estimation. Annual Journal of Coastal Engineering, JACE, 52, 1366-1370. (J)

Minoura, K., Imamura, F., Sugawara, D., Kono, Y. and Iwashita, T. (2001) The 869 Jogan tsunami deposit and recurrence interval of large-scale tsunami on the Pacific coast of northeast Japan. Journal of Natural Disaster Science, 23, 83-88.

Minoura, K., Nakaya, S. and Sato, H. (1987) Traces of tsunamis recorded in lake deposits-An example from Jusan, Shiura-mura, Aomori-. Journal of the Seismological Society of Japan, 40, 183-196. (J+E)

Minoura, K., Nakaya, S. and Uchida, M. (1994) Tsunami deposits in a lacustrine sequence of the Sanriku coast, northeast Japan. Sedimentary Geology, 89, 25-31.

Nakata, T., Koba, M., Imaizumi, T., Jo, W., Matsumoto, H. and Suganuma, K. (1980) Holocene marine terraces and seismic crustal movements in the southern part of Boso peninsula, Kanto, Japan. Geographical Review of Japan, 53, 29-44. (J+E)

Nanayama, F., Satake, K., Furukawa, R., Shimokawa, K., Atwater, B.F., Shigeno, K. and Yamaki, S. (2003) Unusually large earthquakes inferred from tsunami deposits along the Kuril trench. Nature, 424, 660663.

Nanayama, F. and Shigeno, K. (2004) An overview of onshore tsunami deposits in coastal lowland and our sedimentological criteria to recognize them. Memoirs of the Geological Society of Japan, 58, 1933. $(\mathrm{J}+\mathrm{E})$

Nanayama, F., Shigeno, K., Satake, K., Shimokawa, S., Koitabashi, S., Miyasaka, S. and Ishii, M. (2000) Sedimentary differences between the 1993 Hokkaidonansei-oki tunami and the 1959 Miyakojima typhoon at Taisei, southwestern Hokkaido, northern Japan. Sedimentary Geology, 135, 255-264.

Nishimura, Y. and Miyaji, N. (1995) Tsunami deposits from the 1993 southwest Hokkaido earthquake and the 1640 Komagatake eruption, northern Japan. Pure and Applied Geophysics [SD14], 144, 719-733.

Okamura, M., Kurimoto, T. and Matsuoka, H. (1997) Coastal and lacustrine deposits as a monitor for tectonic movements. The Earth Monthly, 19, 469473. (J)

Satake, K. (2005) Tsunamis : Case studies and recent developments. 343 p, Advances in natural and technological hazards research, 23, Springer.

Satake, K. and Nanayama, F. (2004) Tsunami inundation maps for the Pacific coast of Hokkaido. DGM EQ-1, Geological Survey of Japan, AIST. (J)

Satake, K., Nanayama, F. and Yamaki, S. (2003) Source models of the unusual tsunami in the 17 th century in eastern Hokkaido. Annual report on active fault and paleoearthquake researches, Geological Survey of Japan, AIST, 3, 315-362. (J+E)

Satake, K., Nanayama, F. and Yamaki, S. (2004) Source models of the unusual tsunami in the 17 th century in eastern Hokkaido : part 2. Annual Report on Active Fault and Paleoearthquake Researches, Geological Survey of Japan, AIST, 4, 17-29. (J+E)

Shanmugam, G. (2006) The tsunamite problem. Journal of Sedimentary Research, 76, 718-730.

Shiki, T., Cita, M.B. and Gorsline, D.S. (eds.) (2000) Seismoturbidites, seismites and tsunamiites. 326 p, Sedimentary Geology, 135.

Shiki, T. and Yamazaki, T. (1996) Tsunami-induced conglomerates in Miocene upper bathyal deposits, Chita Peninsula, central Japan. Sedimentary Geology, 104, 175-188.

Shuto, N. (1989) Sediment transportation by tsunamis. Tsunami Engineering Technical Report, Tohoku University, 6, 1-55. (J)

Takada, K., Satake, K., Sangawa, A., Shimokawa, K., Kumagai, H., Goto, K. and Haraguchi, T. (2002) Survey of tsunami deposits at an archaeological site along the eastern Nankai Trough. Annual Report on Active Fault and Paleoearthquake Researches, Geological Survey of Japan, AIST, 2, 235-243. (J+E)

Takashimizu, Y. and Masuda, F. (2000) Depositional facies and sedimentary successions of earthquakeinduced tsunami deposits in Upper Pliocene incised valley fills, central Japan. Sedimentary Geology, 135, 231-240.

Tomita, T., Arikawa, T., Yasuda, T., Imamura, F. and Kawata, Y. (2005) Field survey around southwest coast of Sri Lanka on the December 26, 2004 earthquake tsunami disaster of Indian Ocean. Annual Journal of Coastal Engineering, JACE, 52, 1406-1410. (J)

Tsuji, Y., Okamura, M., Matsuoka, H. and Murakami, Y. (1998) Study of tsunami traces in lake floor sediment of the Lake Hamanako. Historical Earthquake (Rekishi Jjishin), 14, 101-113. (J)

Watanabe, H. (1998) Comprehensive list of tsunamis to hit the Japanese Island, 2nd ed. 238 p, University of Tokyo Press. (J)

$(\mathrm{J})$ in Japanese, $(\mathrm{J}+\mathrm{E})$ in Japanese with English abstract. 


\section{津波堆積物の研究は第四紀学にどう貢献したか}

藤原治*

〔要旨〕

大規模な津波は, 重大な自然災害の原因としてだけで

史・観測記録とは桁違いに大きな津波が，過去に 500 年 なく, 沿岸での堆積作用の要因としても重要である。津 波堆積物は, 自然科学と防災工学などの分野で研究さ れ, これらの分野を橋渡しする役割屯担っている. 大規 模な津波はさまざまな場所で, 急速かつ大規模な堆積物 の移動を起こし, 地層の形成や保存に少なからず関わっ ている。

地層中の津波堆積物は, 海溝型地震上津波の履歴復元 に役立っている. この履歴復元は, 南海トラフや駿河卜 ラフでは過去約 3,000 年間, 相模トラフでは約 10,000 年間, 千島海溝では約 6,500 年間に及んでいる。 また, 程度の再来間隔で発生していたことも津波堆積物の研究 から判明した。

いくつかの課題はあるが, 津波堆積物は海溝型地震之 津波の履歴を復元し, 地震と津波による将来のリスクを 評価するのに役立つ. ストームなど他の堆積物との識別 や, 堆積物から津波の流体力の定量的な復元が可能にな れば, 津波堆積物の有用性はさらに向上するだろう. 地質学, 地形学, 地震学, 地球物理学, 津波工学など多 分野の連携によって, こうした問題は解決されると期待 される。

北海道東部では, 遡上範囲が内陸数 $\mathrm{km}$ にも達する歴

キーワード : 沿岸堆積作用, 海溝型地震, 第四紀学, 津波堆積物, 地震・津波防災

* 産業技術総合研究所活断層研究センター $\mathbf{7} 305-8567$ つくば市東 1-1-1 中央第 7. E-mail : o.fujiwara@aist.go.jp 